\title{
Cryopreservation of Marine Unicellular Algae. II. Induction of Freezing Tolerance
}

\author{
A. Ben-Amotz and A. Gilboa \\ Israel Oceanographic \& Limnological Research, Tel-Shikona, P.O.B. 8030, Haifa, Israel
}

ABSTRACT: The induction of freezing tolerance in marine unicellular algae was assayed by measurements of algal viability following storage in liquid nitrogen. Resistance to freezing was induced and developed in cryo-sensitive algae during growth under limiting conditions of low temperature and nutrient deficiency. Algae grown at $4{ }^{\circ} \mathrm{C}$ for 4 weeks developed high resistance to freezing. Deficiency of nutrients such as nitrate, phosphate and bicarbonate slowed the rate of growth and increased significantly the ability of the cell to survive freezing in liquid nitrogen. The observations are interpreted as indicating that reduced metabolic growth of active cells causes augmentation or modification of the cell membrane which serves to increase the resistance to freezing injury.

\section{INTRODUCTION}

Our previous study (Ben-Amotz and Gilboa, 1980) considered the sensitivity of various unicellular marine algae to freezing and storage in liquid nitrogen. Out of a dozen species tested, only a few resisted freezing relatively better than the others. Freezing tolerance was not correlated with culture age, photosynthetic activity or chlorophyll-to-cell ratio. The observation of a natural freezing tolerance in only a few algae gave rise to questions concerning the mechanism of adaptation to freezing and the biochemical and physiological mechanism which permits certain algae to survive freezing better than others. A beneficial approach to the study of the mechanism of freezing tolerance comes from experience gained in higher plants (Yoshida and Sakai, 1973; Wilson and Crawford, 1974; Moore, 1975 i Steponokus, 1980). Resistance of higher plants to injury from chilling may be derived either from an increase of unsaturation of fatty acids in the phospholipids of the membranes (Wilson and Crawford, 1974), from membrane augmentation in the process of freezing adaptation (Singh et al., 1975; Siminovitch, 1979), or from intracellular osmotic adjustment in response to cold acclimation (Steponokus, 1980). A conclusive decision on the main cause of freezing acclimation remains open and warrants further investigation.

The purpose of this communication is to describe the induction of freezing tolerance in marine unicellular algae, its relation to cold acclimation and nutrient deficiency, and the possible effect of low metabolic activity on the resistance of microphytoplankton to freezing.

\section{MATERIALS AND METHODS}

Growth conditions, cooling, freezing and the methodology employed were as previously described (BenAmotz and Gilboa, 1980), with variants indicated in the table legends.

\section{RESULTS}

\section{Efiect of Low Temperature and Nutrient Deficiency on Growth}

Table 1 illustrates the effect of low temperature and nutrient deficiency on the specific growth rate $\left(\mu \mathrm{d}^{-1}\right)$ of various marine unicellular algae. The algae were grown under the specified conditions for 4 weeks and growth was monitored by cell counting every 2 to $3 \mathrm{~d}$. Clearly, low temperature and nutrient deficiency slowed growth to a large extent. Growth at $4{ }^{\circ} \mathrm{C}$ was severely inhibited; however, growth recovered to optimal rate when cold-treated cells were grown under optimal temperature (not shown). In Table 2, the effect of low temperatures and nutrient deficiency on the maximal concentration of algae in cells per $\mathrm{ml}$ is illustrated. Similar to the response of the specific growth rate to suboptimal growth conditions, the maximal concentra- 
Table 1. Effect of low temperature and nutrient deficiency on the specific growth rate $\left(\mu \mathrm{d}^{-1}\right)$ of several marine unicellular algae

\begin{tabular}{|c|c|c|c|c|c|c|}
\hline \multirow[t]{2}{*}{ Species } & \multicolumn{6}{|c|}{ Growth rate $\left(\mu \mathrm{d}^{-1}\right)$} \\
\hline & Control & $4{ }^{\circ} \mathrm{C}$ & $10^{\circ} \mathrm{C}$ & $\begin{array}{c}\text { No } \\
\text { bicarbonate }\end{array}$ & $\begin{array}{c}\text { No } \\
\text { nitrate }\end{array}$ & $\begin{array}{c}\text { No } \\
\text { phosphate }\end{array}$ \\
\hline Chlorella marina & 2.0 & 1.01 & 1.18 & 1.33 & 1.23 & 1.30 \\
\hline ChJorella ovalis & 1.6 & 1.02 & 1.46 & 1.22 & 1.33 & 1.51 \\
\hline Chlorella salina & 2.0 & 1.01 & 1.26 & 1.33 & 1.30 & 1.80 \\
\hline Chlorella spaerckii a & 2.7 & 1.06 & 1.2 & 1.27 & 1.12 & 1.23 \\
\hline Chlorella spaerckii b & 2.7 & 1.08 & 1.08 & 1.20 & 1.18 & 1.36 \\
\hline Nannochloris atomus & 2.5 & 1.02 & 1.40 & 1.25 & 1.29 & 1.45 \\
\hline Nannochloris oculata & 2.5 & 1.06 & 1.28 & 1.10 & 1.15 & 1.22 \\
\hline Nannochloris samiensis & 2.2 & 1.08 & 1.26 & 1.25 & 1.25 & 1.10 \\
\hline Nannochloris $\mathrm{sp}$ & 2.2 & 1.08 & 1.20 & 1.21 & 1.00 & 1.24 \\
\hline Phaeodactylum tricornutum & 2.3 & 1.16 & 1.70 & 1.31 & 1.41 & 1.20 \\
\hline Platymonas suecica & 1.7 & 1.15 & 1.20 & 1.14 & 1.35 & 1.28 \\
\hline
\end{tabular}

Table 2. Effect of low temperature and nutrient deficiency on the maximal algal concentration. Growth conditions as described under Table 1

\begin{tabular}{|lcccccc}
\hline Species & Control & $4{ }^{\circ} \mathrm{C}$ & $\begin{array}{c}\text { Algal concentration (cells ml }{ }^{-1} \text { ) } \\
10^{\circ} \mathrm{C}\end{array}$ & $\begin{array}{c}\text { No } \\
\text { bicarbonate }\end{array}$ & $\begin{array}{c}\text { No } \\
\text { nitrate }\end{array}$ \\
\hline Chlorella marina & & & & $\begin{array}{c}\text { No } \\
\text { phosphate }\end{array}$ \\
Chlorella ovalis & $1.0 \times 10^{7}$ & $1.4 \times 10^{5}$ & $3.0 \times 10^{6}$ & $1.4 \times 10^{6}$ & $5.6 \times 10^{5}$ & $6.0 \times 10^{5}$ \\
Chlorella salina & $1.0 \times 10^{7}$ & $9.8 \times 10^{5}$ & $1.0 \times 10^{7}$ & $9.3 \times 10^{5}$ & $1.1 \times 10^{6}$ & $1.5 \times 10^{6}$ \\
Chlorella spaerckii & $8.0 \times 10^{6}$ & $8.0 \times 10^{4}$ & $6.3 \times 10^{6}$ & $4.4 \times 10^{6}$ & $6.9 \times 10^{5}$ & $5.1 \times 10^{5}$ \\
Chlorella spaerckii $b$ & $4.0 \times 10^{7}$ & $5.4 \times 10^{5}$ & $2.7 \times 10^{6}$ & $3.3 \times 10^{6}$ & $1.3 \times 10^{6}$ & $9.1 \times 10^{5}$ \\
Nannochloris atomus & $2.0 \times 10^{7}$ & $8.0 \times 10^{5}$ & $8.2 \times 10^{6}$ & $1.0 \times 10^{6}$ & $2.5 \times 10^{5}$ & $6.4 \times 10^{5}$ \\
Nannochloris oculata & $6.0 \times 10^{7}$ & $8.3 \times 10^{5}$ & $1.1 \times 10^{7}$ & $1.6 \times 10^{6}$ & $5.6 \times 10^{5}$ & $8.0 \times 10^{5}$ \\
Nannochloris samiensis & $5.0 \times 10^{7}$ & $9.2 \times 10^{5}$ & $4.2 \times 10^{6}$ & $1.5 \times 10^{6}$ & $8.5 \times 10^{5}$ & $4.7 \times 10^{5}$ \\
Nannochloris sp. & $3.5 \times 10^{7}$ & $2.9 \times 10^{6}$ & $9.2 \times 10^{6}$ & $2.9 \times 10^{6}$ & $7.7 \times 10^{5}$ & $4.4 \times 10^{5}$ \\
Phaeodactylum tricomutum & $3.0 \times 10^{7}$ & $1.5 \times 10^{6}$ & $1.2 \times 10^{7}$ & $1.7 \times 10^{6}$ & $4.6 \times 10^{5}$ & $3.9 \times 10^{5}$ \\
Platymonas suecica & $3.0 \times 10^{7}$ & $6.5 \times 10^{6}$ & $2.2 \times 10^{7}$ & $3.4 \times 10^{6}$ & $1.3 \times 10^{6}$ & $6.3 \times 10^{5}$ \\
\hline
\end{tabular}

Table 3. Relation between cold acclimation and freezing resistance in the unicellular algae listed

\begin{tabular}{|c|c|c|c|c|}
\hline \multirow[t]{2}{*}{ Species } & \multicolumn{4}{|c|}{ Viability $(\%)$} \\
\hline & 48 h at $4^{\circ} \mathrm{C}$ & $48 \mathrm{~h}$ at $10^{\circ} \mathrm{C}$ & 4 weeks at $4{ }^{\circ} \mathrm{C}$ & 4 weeks at $10^{\circ} \mathrm{C}$ \\
\hline Chlorella marina & 19.0 & 0 & 45.2 & 22.4 \\
\hline Chlorella ovalis & 6.7 & 0 & 19.8 & 10.0 \\
\hline Chlorella salina & 0 & 39.0 & 100.0 & 12.0 \\
\hline Chlorella spaerckii a & 0 & 13.1 & 28.9 & 3.0 \\
\hline Chlorella spaerckii $b$ & 0 & 7.5 & 44.3 & 7.0 \\
\hline Nannochloris atomus & 0 & 32.2 & 60.4 & 5.0 \\
\hline Nannochloris oculata & 0 & 32.1 & 54.3 & 7.0 \\
\hline Nannochloris samiensis & 0 & 0 & 0 & 3.0 \\
\hline Nannochloris sp. & 9.1 & 2.4 & 20.6 & 8.0 \\
\hline Phaeodactylum tricornutum & 0 & 0 & 0 & 5.0 \\
\hline Platymonas suecica & 0 & 1.4 & 14.9 & 4.0 \\
\hline
\end{tabular}


Table 4. Effect of nutrient deficiency on algal freezing tolerance

\begin{tabular}{|c|c|c|c|c|}
\hline \multirow{2}{*}{ Species } & \multicolumn{4}{|c|}{ Viability $(\%)$} \\
\hline & Control & No bicarbonate & No nitrate & No phosphate \\
\hline Chlorella marina & 8 & 80.5 & 32.1 & 50.5 \\
\hline Chlorella ovalis & 3 & 45.0 & 31.0 & 31.0 \\
\hline Chlorella salina & 5 & 47.5 & 30.5 & 85.0 \\
\hline Chlorella spaerckii a & 4 & 15.2 & 0 & 0 \\
\hline Chlorella spaerckii b & 2 & 65.9 & 0 & 75.4 \\
\hline Nannochloris atomus & 3 & 0 & 9.3 & 44.9 \\
\hline Nannochloris oculata & 3 & 19.6 & 25.1 & 44.3 \\
\hline Nannochloris sarniensis & 2 & 30.9 & 0 & 97.3 \\
\hline Nannochloris sp. & 0 & 0 & 0 & 45.3 \\
\hline Phaeodactylum tricornutum & 0 & 0 & 0 & 0 \\
\hline Platymonas suecica & 0 & 0 & 0 & 0 \\
\hline
\end{tabular}

tion of cells per ml was significantly decreased. It is clear that low temperature and nutrient deficiency reduce the metabolic activity and impair the ability of the algae to grow and multiply at optimal rate.

\section{Effect of Low Temperature on Viability}

In Table 3 , the effect of growth at low temperature on the freezing resistance of the algae in liquid nitrogen is shown. With the exception of Nannochloris sarniensis and Phaeodactylum tricornutum, growth at $4{ }^{\circ} \mathrm{C}$ for 4

Table 5. Combined effect of limiting growth conditions and the two-step cooling procedure on the recovery of cryopreserved algae

\begin{tabular}{|c|c|c|}
\hline \multirow[t]{2}{*}{ Species } & \multicolumn{2}{|c|}{ Viability $(\%)$} \\
\hline & $\begin{array}{l}4 \text { weeks } \\
\text { at } 4{ }^{\circ} \mathrm{C}\end{array}$ & $\begin{array}{c}\text { No bicar- } \\
\text { bonate }\end{array}$ \\
\hline Chlorella marina & 45.2 & 100.0 \\
\hline Chlorella ovalis & 70.0 & 41.0 \\
\hline Chlorella salina & 100.0 & 67.6 \\
\hline Chlorella spaerckii a & 53.6 & 43.0 \\
\hline Chlorella spaerckii b & 48.2 & 82.2 \\
\hline Nannochloris atomus & 75.4 & 58.7 \\
\hline Nannochloris oculata & 63.1 & 68.6 \\
\hline Nannochloris sarniensis & 13.1 & 40.4 \\
\hline Nannochloris sp. & 22.1 & 12.9 \\
\hline Phaeodactylum tricornutum & 36.0 & 33.0 \\
\hline Platymonas suecica & 24.2 & 20.1 \\
\hline \multicolumn{3}{|c|}{$\begin{array}{l}\text { Growth conditions as described under Table } 1 \text {. Concentra- } \\
\text { ted algae were incubated with } 5 \% \text { DMSO at } 20^{\circ} \mathrm{C} \text { for } 15 \\
\text { min, then transferred into a cooling bath at }-30^{\circ} \mathrm{C} \text { for } 15 \\
\text { min, and finally fast cooled in liquid nitrogen. After sto- } \\
\text { rage for } 7 \mathrm{~d} \text {, the algae were thawed at } 30^{\circ} \mathrm{C} \text { and assayed } \\
\text { for viability. }\end{array}$} \\
\hline
\end{tabular}

weeks has by far the largest effect on the induction of freezing tolerance. Algae exposed to $4^{\circ} \mathrm{C}$ for periods of 4 and 48 h resisted freezing in liquid nitrogen poorly. Growth at $10^{\circ} \mathrm{C}$ for $48 \mathrm{~h}$ and for 4 weeks did not induce freezing tolerance in the algae. Clearly, low-temperature acclimation induces freezing tolerance in unicellular marine algae.

\section{Effect of Nutrient Deficiency on Viability}

Nitrate, phosphate and bicarbonate are considered to be the major macronutrients required for algal growth. Table 4 illustrates the effect of nutrient deficiency on the viability of the algae following freezing in liquid nitrogen. Among the nutrients, phosphate deficiency induced freezing tolerance in 9 species, and bicarbonate and nitrate in 7 and 4 species, respectively. It is apparent that nutrient deficiency, like cold acclimation, reduces growth rate and induces resistance to freezing in the algae.

\section{Relation to Two-Step Technique}

Table 5 illustrates the combined effect of a two-step freezing technique and nutrient deficiency on the recovery of frozen algae. The cryoprotective agent DMSO and the two-step technique increase algal viability independently of the growth conditions. However, induction of freezing resistance in algae by cold acclimation and growth under nutrient starvation, jointly with the two-step procedure, resulted in higher algal viability. The effect of DMSO on partially freezing-resistant algae is by far the most successful treatment for algal cryopreservation. 


\section{DISCUSSION AND CONCLUSIONS}

It was previously shown that the adaptation of higher plants to freezing through growth and frost acclimation is correlated with augmentation of membranous material in the phospholipids of the plant cell (Singh et al., 1975) or with an increase of unsaturation of the membrane lipids (Yoshida and Sakai, 1973). These results were interpreted in view of the generally-accepted working hypothesis for freezing hardiness (Moore, 1975) which postulates that it results from augmentation of membrane proteins and phospholipids per cell basis or from changes of lipid unsaturation and fluidity of membrane lipids.

Our observations on cold acclimation and nutrient starvation inducing freezing tolerance in marine algae illustrate the complex nature of algal cryopreservation. Growth at low temperatures and nutrient deficiency were expressed phenomenologically by a marked decrease in the specific growth rate and maximal concentration of cells per ml. It might be argued, therefore, that unfavorable growth conditions which slow algal division rate and reduce metabolic activity are associated with freezing acclimation and cellular resistance to freezing. At this stage, it is too early to decide whether freezing-tolerance induction in algae involves changes in lipid unsaturation or membrane augmentation. Moreover, algal resistance to extracellular freezing injury may also be related to cellular dehydration and intracellular solute accumulation (Steponokus, 1980). The data indicate, however, that algae grown under unfavorable conditions develop the intrinsic chemical and physical properties which endow them with tolerance to freezing. Our comparison of different species shows a few strains with a better original tolerance to freezing than others. These differences may be related to natural properties of different membranes or to different concentrations of various intracellular organic solutes produced by the algae. The properties of the membranes of marine unicellular algae and the nature of the internal solutes remain uncertain and warrant detailed investigation.

Acknowledgements. This study was supported by a grant from the National Council for Research and Development, Israel, and the GKSS Geesthacht-Tesperhude, Federal Republic of Germany

\section{LITERATURE CITED}

Ben-Amotz, A., Gilboa, A. (1980). Cryopreservation of marine unicellular algae. I. A survey of algae with regard to size, culture age, photosynthetic activity and chlorophyll-tocell ratio. Mar. Ecol. Prog. Ser 2: 157-161

Moore, P. D. (1975). Adapting to chilling future. Nature, Lond. 253: $11-12$

Morris, G. J. (1978). Cryopreservation of 250 strains of chlorococcales by the method of two-step cooling. Br. Phycol. J. 13: 15-24

Siminovitch, D. (1979). Protoplasts surviving freezing to $-196^{\circ} \mathrm{C}$ and osmotic dehydration in 5 Molar salt solutions prepared from the bark winter black locust trees. Pl. Physiol. Wash. 63: 722-725

Singh, J., de la Roche, J. A., Siminovitch, D. (1975). Membrane augmentation in freezing tolerance of plant cells. Nature, Lond. 257: 699-700

Steponokus, P. L. (1980). A unified concept of stress in plants. In: Rains, D. W., Valentine, R. C. (eds) Genetic engineering of osmoregulation. Plenum Press, New York, in press

Wilson, J. N., Crawford, R. M. (1974). Leaf fatty acids content in relation to hardening and chilling injury. J. exp. Bot. 25: 121-131

Yoshida, S., Sakai, A. (1973). Phospholipid changes associated with the cold hardiness of cortical cells from poplar stem. Pl. Cell Physiol., Tokyo 14: 353-359 